\title{
GIMTOJI KALBA KAIP BŪSIMŲJŲ KARININKŲ TAUTINIO KULTŪRINIO TAPATUMO RAIŠKOS MATMUO
}

\author{
Doc. dr. Janina Bukantienė
}

Klaipédos universitetas

\author{
Doc. dr. Nijolė Janulaitienè \\ Generolo Jono Žemaičio Lietuvos karo akademija
}

\section{Prof. habil. dr. Ona Tijūnėlienè}

Klaipédos universitetas

\begin{abstract}
Anotacija. Straipsnyje pateikiami būsimujų karininku santykio su gimtaja kalba, esminiu tautinio tapatumo raiškos matmeniu, tęstinio tyrimo rezultatai. Išryškinamos globalizacijos grèsmès tautu kultūroms, kalbos gyvybingumui, asmens vertybiu sistemai. Pristatyti Generolo Jono Žemaičio Lietuvos karo akademijos kariūnu tautinio tapatumo patirties ir jo raiškos kaitos daugiakultūrèje aplinkoje kokybiniu tyrimu (2011 ir 2015 m.) rezultatai. Taikant lyginimo metoda, nustatyti respondentų kultūrinio identiteto raiškos lygmenys.
\end{abstract} riūnai.

Pagrindiniai žodžiai: tautinis tapatumas, individualumas; globalizacija, kalba, ka-

Ivvadas. Žymus kalbininkas A. Mejë (Antoune Meillet; 1886-1936) XX pr. atkreipe europiečių dèmesị, kad lietuvių kalba yra itin svarbi Europos kultūros dalis: ji yra tarsi daugybès Europos kalbų pamatas. Unikali, mokslo tyrimams reikšminga lietuvių kalba, pasižyminti kalbos formų ịvairumu, archaiškumu, dvasingumu, sulaukia vis didesnio užsienio šalių mokslo institucijų susidomejjimo.

Nors šiandien Europos Sajungos kalbų politika skatina išlaikyti Europos kalbų įvairovę, kuri laikoma viena didžiausių vertybių (Veiksmų plano „Kalbų mokymosi ir kalbų įvairovès skatinimas“ igyvendinimo ataskaita. Briuselio komunikatas. (2007)), tačiau globalizacija atlieka nacionalinių kultūrų ir kalbų ardomają (griaunamają) funkciją, todèl lietuviai, kaip ir didelè Europos tautų dalis, ne visada suvokia šio brangaus turto vertę, t. y. kad kalba - tai tautos gyvasties, jos prigimtinio tapatumo pagrindas, nes net netekusi valstybingumo, priešui okupavus jos teritoriją, tauta dar gali likti gyva, jeigu jos nariai vartos savo gimtają kalbą. 
Pasirinktos temos aktualumą ir reikšmingumą atskleidžia ir naujausi Lietuvos dokumentai. Tai „Lietuvos pažangos strategija „Lietuva 2030“, ịtvirtinanti du reikšmingus principus: „Nacionalinè tapatybè, istorijos pažinimu grịstas tradicijos tęstinumas ir atvirumas kultūrų ịvairovei“ ir „Humaniškumas, demokratiškumas ir lygios galimybės, pilietiškumas, laisvės realizavimas ir etika, tolerancija ir dialogiškumas“ (p. 2). Šiuos pažangos strategijos principus praplečia ir kitas dokumentas - „Valstybinè švietimo 2013-2022 metų strategija“, teigiantis, jog globalizacijos amžiuje svarbu ,iš naujo persvarstyti savo tautini tapatuma, suvokti, kas mus (iskaitant išvykstančiuosius iš Lietuvos ir atvykstančiuosius čia gyventi) vienija ir sieja su Lietuvos valstybe“" (p. 4).

Problemos ištirtumas. Lingvistiniu požiūriu lietuvių kalbą įvairiais atžvilgiais nagrinėjo XX a. pab. - XXI a. pr. lietuvių ir užsienio šalių mokslininkai. V. Ambrazas rašè, kaip svarbu išsaugoti lietuvių kalbą (1989); M. Martinaitis nagrinèjo kalbos kultūros klausimus (1989); A. Zabotka atkreipè dẻmesị ị pagarbos kalbai ugdymą (1989); A. Rosinas aptarè komunikacinę kalbos funkciją (1989) ir kt. Atgavus Nepriklausomybę, pradẻjus leisti lietuvių pedagogikos klasikų darbus, Lietuvos skaitytojas susipažino su A. Maceinos kultūros ir kalbos santykio koncepcija $(1990,1998)$, Vydūno kalbos kilmès ir raiškos aiškinimu (1990), su V. Zaborskaitès mintimis apie visų lietuvių pareigą saugoti kalbą.

Iš tautinį tapatumą ir jo raišką tyrinèjusių užsienio šalių autorių paminètini H. Giles, D. Taylor, W. Lambert, G. Albert (1976), kurie bandè ịvertinti tautinio tapatumo matmenis; D. O. Searsas (1999) ir jo kolegos, tyrę asmens tautinị identitetą; R. Usher, R. Edwards (2008), rašę apie identitetą erdvès ir laiko požiūriu; A. Giddens, gilinęsis ị modernumo ir asmens tapatybès klausimus (2000).

Asmens tautinio tapatumo ir jo raiškos kalba klausimai Lietuvoje yra labai aktualūs, bet šios problematikos tyrimų dar stokojama. Lietuvoje etnocentrizmo problemas, kylančias stiprejjant globalizacijai ir migracijai, tyrẻ R. Jančaitytė, N. Valavičienè, R. Augutienė, R. Prakapas (2009); B. Kuzmickas - vertybiu problemą kultūrų kontekstuose (2013), tautos tapatumo savimonę (2007), lietuviškaji europietiškumą (2006); L. Duoblienè - švietimo politikos nacionalinius ir supranacionalinius ypatumus globalizacijos erdveje; D. Antinienè - asmens tautinio tapatumo tapsmą (2006); L. Astra gvildeno tautiškumo ir lietuvių tapatumo problemas globalioje modernybëje (2006); R. M. Vabalaitė - moderniają tapatybès sampratą (2006). E. Martišauskienè, A. Juškevičienè paskelbė publikacijų apie gimtosios kalbos puoselèjimą, kaip mokinių tautinio ugdymo veiksni (2011). J. Bukantienè, N. Janulaitienè, O. Tijūnèliené 2011 ir 2015 m. tyré Lietuvos akademinio jaunimo tautinio kultūrinio identiteto autentiškumo raišką.

Tyrimo objektas - gimtosios kalbos reikšmè akademinio jaunimo tautinio tapatumo formavimuisi ir raiškai.

Tyrimo problema - gimtoji kalba kaip akademinio jaunimo tautinio kultūrinio tapatumo raiškos matmuo.

Tyrimo tikslas - ištirti ir nustatyti gimtosios kalbos reikšmę būsimųjų kari- 
ninkų tautiniam kultūriniam tapatumui ir jo raiškos kaitai.

\section{Tyrimo uždaviniai:}

1. Apibūdinti asmens tautinio tapatumo ugdymą(si) deformuojančius veiksnius.

2. Atskleisti tautos ryši su kalba kaip individualumo ir tapatumo raiškos matu.

3. Empiriškai ištirti, nustatyti ir palyginti būsimųjų karininkų santykị su gimtaja kalba, kaip jų tautinio kultūrinio tapatumo raiškos kaitos matą.

Teoriniai tyrimo metodai: analizè, lyginimas, sisteminimas ir abstrahavimas.

Tyrimo metodologinès nuostatos. Vertybės ir vertès konstruojamos žmogaus santykiuose su aplinkiniu pasauliu. Kalbos, galvosenos, bendravimo ir kitokia pasirinkimo teisè suteikiama kiekvienam individui - vyrauja nuomonių pliuralizmas. Laisvè rinktis kalbą, žodị yra socialiai kuriama, ji priklauso nuo aplinkos, asmens žinių, gebẻjimų, ịūdžių, vertybių, kartais ir nuo vartotojiškojo pragmatizmo. Informacijos ir žinių visuomenèje keičiasi pažinimo tikslas: žinių igijimas, jų gausa nebėra asmenybės ugdymo(si) tikslas, bet dažnai jis tampa preke, gal net kovos dèl pripažinimo objektu (J. F. Lyotard, 2010).

Fenomenologiniu požiūriu asmens savikūros procese svarbi refleksija, kuri labiausiai yra siejama su patirtimi. Pažinime vienodai svarbus subjektyvus patyrimas ir objektai. Idejjos, objektai, daiktai žmonėms įgauna reikšmę tik per jų sąmonę, t. y. pasaulis yra toks, kokią reikšmę daiktams suteikia žmonès (E. Husserl, 2005). Taip nereikšmingi objektai tampa reikšmingais, jie gali veikti žmogaus sąmonę ir elgesị, kurti prasmes. Priimtają prasmę kiekvienas individas gali patvirtinti tik savo esybės nepakartojamumu, santykio tarp Aš ir Tu spontaniškumu (M. Buber, 1998, 2001).

\section{Globalizacija - asmens tautinị kultūrinị tapatumą griaunantis veiksnys}

Tautinio tapatumo esmę, jo reikšmę ir prigimtinị poreikị asmens gyvenime atskleidè lietuvių filosofijos klasikai A. Maceina, S. Šalkauskis, nūdienos užsienio ir lietuvių mąstytojai Jonas Paulius II, J. M. Gerson, H. Giles, D. Taylor, W. Lambert, B. Kuzmickas ir kt. Tad tektų tik apibendrintai ịvardyti pagrindinius tautinio tapatumo elementus, kuriuos Anthony Smithas knygoje „Nacionalizmas XX amžiuje“ išskyre lietuvių filosofas B. Kuzmickas: ,a) „mes - bendruomenès“ savimonė, susijusi su bendros istorinès teritorijos ir praeities atmintimi; b) bendra masinè kultūra; c) bendros pilietinès teisès ir priedermès; d) bendra ekonomika ir gyvenamoji teritorija“" (B. Kuzmickas, 2007, p. 43).

Šiandien globalizacijos plètros sąlygomis keičiasi požiūris ị tautiškumą, pilietiškumą. Daugelis ịvairiausių ženklų rodo, kad šio požiūrio kaita objektyvi ir vis labiau stipreja. Kinta tautos ir valstybės ryšys, tautiškumą palaikančių veiksnių pobūdis. B. Kuzmickas išsamiausiai aptaria šiuos iššūkius, kilusius tautiškumui:

- atskiroms tautoms vis labiau integruojantis ị Europos Sajungą, atsiranda 
tradicinius dalykus keičiantys veiksniai: nacionaliniai įstatymai derinami su Europos Sajungos įstatymais, nacionalinè pilietybè tampa ir europine;

- plečiasi legalaus darbo jègos judejjimo galimybès, ekonomika peržengia nacionalinị uždarumą, nacionalinę valiutą keičia Europos piniginis vienetas; nėra palanki jaunimo tautiškumui ir pilietiškumui stiprinti ir laisvo individų judejimo erdvès plètra: ji daro paslankius tautiškumo ir pilietybės ryšius. Lietuvai tapus Europos Sajungos nare, tampa neišvengiamas Lietuvos piliečio tapatinimasis ne tik su Lietuva, bet ir su daug platesne Europos erdve, ypač jeigu su ja sieja darbo arba asmeniniai ryšiai;

- globaliosios sąveikos lemia, kad valstybè vis labiau nušalinama nuo ekonomikos, nes privatizuojamos ne tik valstybès įmonès, bet ir viešosios sritys: transportas, švietimas, komunikacijos ir informacijos priemonès;

- jaunimo kultūrinio identiteto savitumui formuotis ir reikštis šiandien turi reikšmės vienas iš tautinès valstybès silpnèjimo momentų - besikeičianti gynybinė jos funkcija; Lietuvos teritoriją dabar netiesiogiai saugo ir tie lietuviai kariai, kurie tarnauja tarptautinèse pajègose toli nuo Tèvynès. Anot B. Kuzmicko, jaunimo tarnyba kitų šalių kariuomenèse gali ugdyti ir svetimų kultūrų patriotus (2007, p. 44-45).

Nors autorius ir teigia, kad „<..> kol kas niekas negali aiškiai pasakyti, kokie tautų valią ịkūnijantys politiniai modeliai galètų pakeisti tautines valstybes, kaip tvarkysis ateities visuomenès“ (B. Kuzmickas, 2007, p. 43), tačiau objektyvi realybė egzistuoja - tarp piliečių ir valstybès pradeda atsiverti praraja.

İ tokị patị tikslą orientuota Europos Sajungos politika. Nors imigracijos ị Vakarų šalis srautai yra labai dideli, ir šis reiškinys yra palankus tradiciniam tautybès ir pilietybės ryšio supratimui, bet Europos Sajungos siekinys - pilietiškumas, deja, turintis gana silpną ryši su tautiškumu.

Išlaikyti ir stiprinti tautini tapatumą trukdo sovietinio palikimo padariniai: žiniasklaidoje ir viešojoje nuomonèje ịsitvirtinę seno mąstymo stereotipai, atviras abejingumas pilietinėms ir moralinèms vertybèms ir tautiškumui kaip fenomenui apskritai. Tokie požiūriai būdingi net daugeliui „,naujalietuvių“, kurie nèra tiesiogiai nomenklatūrinio palikimo perėmejjai, tačiau jie brendo „vertybių nuvertẻjimo“ aplinkoje, nematė kitokių materialinès gerovès siekimo būdų, išskyrus tik buvusios sovietinès nomenklatūros įtvirtintuosius.

Prie tarp tautiškumo ir valstybės atsiradusios prarajos priežasčių autorius priskiria ir medijas: jos perša universalumo elementus ir natūraliai skiepija kosmopolitinius požiūrius. Nors laisvai prieinami informacijos srautai plečia žmonių akiratị, ugdo kultūrinę ir religinę toleranciją, bet kartu atveria galimybes ir prastos kokybės ir neprasmingo turinio komercinei kultūrai, kuri slopina žmogaus supratimą apie savo esmę. Visi minèti dalykai formuoja kosmopolitinę mąstyseną (B. Kuzmickas, 2007, p. 181).

B. Kuzmicko keliama idèja apie žmogaus esmę artima lietuvių švietèjo Vydūno dar XX a. I pusèje iškeltai minčiai: kalbant apie tapatumą, svarbiausia ne ịgimta 
savitumų visuma, kuri yra tik iš gamtos dovanų gaunamas fizinio tapatumo pamatas, bet asmenybiškasis žmogaus matmuo, kuris sąmoningai ugdomas ir kuriamas. Tai daroma tik individui angažuojantis laisvai pasirenkamoms vertybėms, pagal kurias jis renkasi gyvenimo tikslus. Mokslininkas cituoja J. P. Sartrą (J. P. Sarttre‘as), teigusị, kad „žmogus yra tuo, kuo pats save padaro“ (B. Kuzmickas, 2007, p. 10). Kadangi pasirinkimo laisvè nèra visiškai absoliuti, negali būti ir visavertès savirealizacijos galimybių. Tad autorius daro išvadą, kad individo asmenybiškaji tapatumą reikètų suprasti kaip metų slinktyje jo išlaikomą pagrindinę vertybinę nuostatą, grindžiamą pareiga ir atsakomybe.

Panašias mintis kelia R. Vasiliauskas: globalizacija kelia grèsmę tautiniam tapatumui, stiprina Vakarų kultūros, ypač masinès, plitimą, stabdo pastangas išsaugoti tautinị paveldą, etniniu pagrindu susiformavusias dvasinio ugdymo tradicijas. Šiandien prarandama tai, ką žmonės laiko svarbiausiu dalyku, - tautinis ir dorovinis ryšys su kitu žmogumi. Esant tokiai situacijai, kai ugdymo praktikoje pagarba žmogui, tiesai, teisingumui, atsakomybei nekeliama kaip pagrindinis ugdymo tikslas, sunku tikètis, kad galima parengti dvasingą žmogų, atsakingą pilietį, atitinkantį moderniosios visuomenès reikalavimus. Nūdienos permainų kontekste iškyla pavojus jaunajai kartai prarasti dorovinius orientyrus (R. Vasiliauskas, 2012, p. 410).

L. Astra pabrèžia ypač didelę modernybès įtaką jaunimui: keičiasi kartos, keičiasi gyvenimo prioritetai, jauni žmonès vis labiau linksta estetizuoti ir naujai konstruoti savo išvaizdą, gyvenimo būdą, siekia pomodernizmo laikotarpiui būdingo savęs pateikimo, derinasi prie naujos sociokultūrinès realybės. Akivaizdu, kad globali modernybė peržengė nacionalinių politinių institucijų nubréžtas ribas.

Autore pažymi, jog globalizacija siūlo pragmatizmą: vartoti tai, kas pelninga, naudinga, greitai ir lengvai pasiekiama, naudotis tarptautinės bendrijos ryšiais. Tai šiandien įmanoma. Net tokios pamatinès vertybès kaip tautinè kilmė daro įtaką sociokultūrinei kaitai. Šiuolaikinei globaliajai kultūrai būdinga skirtingų kultūrų integravimasis $\mathfrak{i}$ ją - platesniame kontekste visos nacionalinès kultūros tampa subkultūromis, jos adekvačiai suvokiamos jų pačių kultūrinès aplinkos visumoje (L. Astra, 2006).

\section{Kalba - tautos individualumo raiškos matas}

Lietuvių filosofijos klasikas A. Maceina pažymi, kad kalba, būdama pirmasis tautos kūrybos stebimojo pažinimo rezultatas, geriausiai atspindi tautos dvasią. Iš kalbos galima spręsti, kaip tauta suvokia pasauli, koks jos santykis su ją supančiais objektais, kokia jos istorija. Kalboje atsispindi ir tautos intelektualumas, socialinis charakteris, meninis polinkis, estetiniai sugebejjimai. pasaulio suvokimo būdas - visas jos individualumas. Kalboje „gyvena visi tautos turtai, josios tradicijos, istorija, religija ir gyvenimo dèsniai, visa josios širdis ir siela“(A. Maceina, 1990, p. 196).

A. Maceina aiškina, kad kalboje glūdi tautos mąstysena ir pasaulèvaizdis. Žodis išreiškia intuityviai suvoktų daiktų ypatybes, atitinka tų daiktų pažinimo 
būdą, kuris yra artimas tautai. Tauta kuria kalbą savitai, todèl tautos kalboje žodis tiksliai atspindi žodžio ir daikto ryši. Daiktas žodžiu pavadinamas taip, kaip pažino protas. Suvoktas daiktas sąmonèje iqgyja savitą atspalvị. Todèl žodyje glūdi ịkūnyta daikto ypatybė, bet tik taip, kaip ją suvokia protas. Daikto ypatybe žodi pasiekia tik per protą. A. Maceina šias mintis grindžia vokiečių keliautojo J. Herderio pastebėjimu: „Tauta neturi nè vienos idejos, kuriai neturètų žodžio“ (ten pat, p.197). Antra vertus, tauta neturi nė vieno žodžio, kuriame neglūdètų kokia nors idèja. Tauta savo kalba išreiškia pažiūras ị pasaulị ir ị gyvenimą, nes kuria žodžius taip, kaip suvokia daiktus.

Taigi tauta ị kalbą „sudeda“ visą save. Kalba - pirmasis, aiškiausias ir reikšmingiausias požymis, kuriuo viena tauta skiriasi nuo kitos. A. Maceinai imponuoja vokiečiu filosofo K. Wosslerio mintys: ,jei mūsų stebejjimas būtų labiau išlavèjęs, galètume iš kalbančio asmens veido ir gestų, negirdẻdami net jo žodžių, įspèti, kokiam kraštui jis priklauso ir kokios tautos yra narys“"(A. Maceina, 1990, p. 199).

Lietuvių švietėjas Vydūnas pastebėjo, kad kalbėdamas žmogus atskleidžia savo dvasią. Švietejjo teigimu, mąstančiam žmogui nekelia abejonių, kad kalba yra žmogaus esmès raiškos būdas ir vienas ryškiausiujjų žmogaus kūrinių. Pats kalbèjimas Vydūnui švietèjui primena kūrybinio proceso slèpini. Šio mąstytojo teigimu, kalba yra dvasinès prigimties reiškinys. Todèl švietèjas įsitikinęs, kad dẻl šios priežasties kalba traukia tyrinètojus. Kalba didelè vertybè, tą jaučia visi žmonès, ypač ją brangina, nes ją paveldi iš tèvų. „Bet didysis jos nuostabumas, jos turiningumas ir reikšmingumas tiktai tam aiškejja, kurs jos esmę tiria“, - nurodo švietėjas (Vydūnas, 1990, p. 483).

V. Zaborskaite gimtają kalbą pavadino viena iš ryškiausių žmogaus tautinio tapatumo požymių; per gimtają kalbą žmogus yra susijęs tiek su savo paties buvimu, tiek su savaja tauta. Todèl ịaugimas ị kalbą yra išgyvenamas kaip kažkas sava ir ịprasta. Žmogus gyvena tarsi paniręs ị savo gimtają kalbą, dažnai nejausdamas ir nereflektuodamas jos taip, kaip oro, kuriuo kvejpuoja. Dažniausiai kalbos svarbą žmogus pajunta, kai susiduria su kita, svetima kalba, nesuprantama ar vos tik pramokta. Tada patiriama, kaip gera sutikti savo gimtaja kalba šnekantijj. Žmonès per kalbos bendrumą pajunta vienas su kitu glaudų ir artimą ryši, tarsi būtų giminès (V. Zaborskaite, 1993, p. 57).

Kalbą profesore pavadino esminiu tautos narius jungiančiu ryšiu, kuris pasireiškia daugelyje lygmenų: nuo kasdienio, buitinio bendravimo iki filosofijos, poezijos, maldos - aukščiausių žmogaus dvasios raiškos formų. Gimtają kalbą žmogus suvokia ir išgyvena kaip vertybę: myli, brangina, yra pasirengęs ginti, kai į jos teises kas nors ima kèsintis. Gimtają kalbą tautos iškelia ir sureikšmina ypač tada, kai joms iškyla pavojus. Tai lietuviai žino ir iš savosios istorijos (Zaborskaitè, 1993, p. 58). Autore atkreipia dèmesị i XVIII a. vidurị, kai germanizacijos politika Mažojoje Lietuvoje vis labiau grūmojo tirpstančiam lietuviškumui.

Mokslininkè pažymi, kad tikra meilè visados yra veikli. Tad gimtają kalbą 
mylèti - vadinasi, pirmiausia žiūrèti, kad ji skleistųsi visa savo esme: jai būdingu skambèjimu, žodžių sandara ir kaityba, žodžių junginiais ir prasmèmis. Kad jos negožtų svetimybès, netaisyklingumai, griaunantys patị branduolị - sistemą. Rūpinimasis ir atsakomybė už gimtają kalbą gula ant kiekvieno tautos nario pečių. Kiekvienas kalbą esame paveldejję iš tẻvų ir protėvių ir turime ją perduoti ateinančioms kartoms. Todèl už jos gyvybę atsakome visi savo pačių elgesiu ir gyvenimu (Ten pat, p. 59).

\section{Būsimųjų karininkų santykio su gimtąja kalba empirinis tyrimas}

Tyrimo dalyviu charakteristika. Siekiant atskleisti asmens individualiąsias vertybines nuostatas ir jų kaitą studijuojant aukštojoje karo mokykloje pasirinktas tęstinis tyrimas. Pirminis tyrimas vykdytas prieš ketverius metus (2011 m.), respondentams tik įstojus studijuoti aukštojoje mokykloje, o pakartotas su tais pačiais respondentais, bebaigiančiais studijas 2015 metais. Tyrimo patikimumą rodo tai, kad buvo fiksuojami kiekvieno asmens individualieji poreikiai, užtikrinantys teorinio ir praktinio mokymosi visą gyvenimą dermès refleksiją, atskleidžiant socialines kultūrines respondento veiklos sąlygas, buvo ịvardijami kultūrinị identitetą formavę veiksniai (C. R. Christensen, 2010).

Tyrime dalyvavo 22 Generolo Jono Žemaičio Lietuvos karo akademijos kariūnai. Tiriamujų amžius nuo 20 iki 24 metų, todèl respondentus galima apibūdinti kaip atsakingai ir tikslingai pasirinkusius kariškio profesiją žmones. Iš jų -5 merginos ir 17 vaikinų. Visų jų gimtoji kalba yra lietuvių. Imties vienetai iš generalinès aibès atrinkti taikant tikslinę kriterinę atranką.

Tyrimas vykdytas 2011 ir 2015 m. spalio-lapkričio mènesiais. Atsižvelgiant $\mathfrak{i}$ bendruosius tyrimo etikos principus, ypač savanoriškumo principą, kiekvienas tyrimo dalyvis galëjo laisvai apsispręsti dèl dalyvavimo tyrime. Siekiant gauti kuo išsamesnius atsakymus, dalyvių buvo paprašyta pateikti esė refleksijas raštu anonimiškai.

Tyrimo instrumentas - esè (angl. essay < pranc. essai - bandymas) - subjektyvus, laisvas, be griežto nuoseklumo minčių dèstymas rašinyje (TŽŽ, 2008). Esė - tai tikslinga komunikacinè veikla, kurioje atsispindi rašančiojo gebejjimai mąstyti, reikšti mintis raštu: būti raštingam kalbos atžvilgiu, gebèti naudotis turimo žodyno arsenalu, žinoti kalbos struktūrą ir gebèti ja pasinaudoti atliekant kelias skirtingas socialines funkcijas (J. Sheilsas, 1995, J. Gee, 1998). Esė būdingas mokslinio, publicistinio ir meninio stiliaus elementu jungimas - pasirinkta tikslingai, kad respondentai galètų neskubėdami raštu reflektuoti turimas žinias, atskleisti savo nuostatas ir kalbos priemonėmis demonstruoti pasirengimą veikti pasirinkus tikslingą profesiją.

Empirinio tyrimo rezultatu analize. Karo mokslus studijuojančio akademinio jaunimo kultūrinio identiteto raiškos kaitos atskleidimas - svarbus uždavinys, identifikuojantis jų savasties ugdymo(si) problemas ir jų autentišką raišką. 
Manoma, kad refleksija kariūnams padèjo:

- geriau suprasti tautinio tapatumo stipriąsias ir silpnąsias puses;

- išsiaiškinti savo pagrindines vertybines nuostatas, viltis ir lūkesčius;

- sužinoti galimas savo idejų, jausmų, veiksmų prielaidas;

- pripažinti savo abejojimus, baimes, galimus neatitikimus.

Respondentų santykị su pilietiškumo ir kultūrinio tapatumo žiniomis, vertybinėmis nuostatomis ir poreikiu aktyviai veikti atskleidžia tyrimo duomenys:

Respondentų tautinio ir kultūrinio identiteto raiška esė darbuose (2011 ir 2015 metų tyrimuose), anot B. Bitino ir kt. (2008), skleidžiasi, keliomis subkategorijomis pradedant nuo realybės ir baigiant vizija, pasireiškiančia ateities darbuose (žr. 1 lentelę).

1 lentelè. Respondentų santykio su tauta raiškos kaita

\begin{tabular}{|c|c|c|c|}
\hline \multicolumn{2}{|c|}{2011 metų tyrimo rezultatai } & \multicolumn{2}{|c|}{2015 metų tyrimo rezultatai } \\
\hline $\begin{array}{l}\text { Subka- } \\
\text { tegorija }\end{array}$ & Argumentai & $\begin{array}{l}\text { Subka- } \\
\text { tegorija }\end{array}$ & Argumentai \\
\hline $\begin{array}{l}\text { Savęs kaip } \\
\text { tautos } \\
\text { atstovo } \\
\text { pažinimas }\end{array}$ & $\begin{array}{l}\text { Mano vardas yra lietuviškas, } \\
\text { senas, reiškiantis audra (7); } \\
\text { Pavarde sudurtinè: „gin“" } \\
\text { reiškia ginti, eiti, judèti. Nors } \\
\text { šios šaknys prūsiškos, mano } \\
\text { protèviai gyveno Lietuvoje, } \\
\text { Krakiuose (21). } \\
\text { Aš iš prigimties lietuvis (16). }\end{array}$ & $\begin{array}{c}\text { Savęs kaip } \\
\text { tautos } \\
\text { kultūros } \\
\text { atstovo } \\
\text { vertinimas }\end{array}$ & $\begin{array}{l}\text { Aš nebandau atitikti nei tauti- } \\
\text { niam, nei kultūriniam lietuvio } \\
\text { tapatumui (7). } \\
\text { Stengiuosi laikytis tautos tra- } \\
\text { diciju, kultūros, nes to išmokè } \\
\text { šeima, giminè. Bet aš- } \\
\text { laisvas žmogus, kuriu savas ir } \\
\text { perimu bendrakultūrines ver- } \\
\text { tybes (21). }\end{array}$ \\
\hline $\begin{array}{c}\text { Tautos } \\
\text { kultūros } \\
\text { pažinimas }\end{array}$ & $\begin{array}{l}\text { Būdamas didelis Lietuvos } \\
\text { patriotas aš labai domiuosi } \\
\text { Lietuvos istorija, jos meno } \\
\text { tradicijomis (4). } \\
\text { Mamos noras uždegti mane } \\
\text { meile Tèvynei, savo gimtajam } \\
\text { kraštui paskatino mane domé- } \\
\text { tis istorija. Dèl to èmiau pati } \\
\text { gilintis ir vertinti tai, ka suži- } \\
\text { nau iš kitu. Filmai, literatūra, } \\
\text { muzika, ịvairūs renginiai tikrai } \\
\text { buvo ir yra tie dalykai, kurie } \\
\text { motyvavo ir po truputi diegé } \\
\text { meilę savo šaliai, jos istorijai. }\end{array}$ & $\begin{array}{c}\text { Tautos } \\
\text { kultūros } \\
\text { vertinimas }\end{array}$ & $\begin{array}{l}\text { Lietuviai-kaip savita tauta, } \\
\text { žinoma pasaulyje pirmiausia } \\
\text { sporto srityje (6). Jos infras- } \\
\text { truktūra bei geografinè padètis } \\
\text { išskirtinè (3). Lietuviams nèra } \\
\text { šiandien būdingi vieningumo, } \\
\text { tarpusavio susiklausymo bruo- } \\
\text { žai (20). Kultūros srityje mes } \\
\text { nesame išskirtiniai,- daugiau ì } \\
\text { tarpkultūrinę erdve isiliejame } \\
\text { (14). }\end{array}$ \\
\hline
\end{tabular}




\begin{tabular}{|c|c|c|c|}
\hline $\begin{array}{c}\text { Požiūris } \\
\text { i gimtąją } \\
\text { kalbą }\end{array}$ & $\begin{array}{l}\text { Gimtoji kalba visuomet buvo } \\
\text { ir tebèra tas dalykas, kuriuo } \\
\text { didžiuojuosi ir kuri vertinu (4). } \\
\text { Gimtaja savo kalba puoseleju, } \\
\text { kalbu tik taisyklinga lietuviu } \\
\text { kalba(15). }\end{array}$ & $\begin{array}{c}\text { Kalbos } \\
\text { kaip savo } \\
\text { tapatumo } \\
\text { vertinimas }\end{array}$ & $\begin{array}{l}\text { Lietuvių kalba-tai mano } \\
\text { Tévynès komunikacijos prie- } \\
\text { moné, kuri leidžia perteikti } \\
\text { informacija, jausmus savo } \\
\text { śeimai (4). } \\
\text { Tai tarsi priimta konstanta (9). } \\
\text { Ši kalba - mano gimtoji, ja } \\
\text { didžiuojuosi, mano tarnyboje } \\
\text { ji yra labai svarbi, nes repre- } \\
\text { zentuoja mane kaip lietuvi kari } \\
\text { ir išsilavinusì žmogu (15). }\end{array}$ \\
\hline $\begin{array}{c}\text { Kas aš } \\
\text { esu }\end{array}$ & $\begin{array}{l}\text { Būti lietuviu man didžiulè gar- } \\
\text { bé (2). Šiuo metu savęs tikrai } \\
\text { negaléčiau pavadinti inteli- } \\
\text { gentu, nors turiu inteligentišku } \\
\text { savybiu, kurias bandau ug- } \\
\text { dytis, tačiau noredamas save } \\
\text { vadinti inteligentu dar daug ko } \\
\text { privalau išmokti (11). }\end{array}$ & $\begin{array}{c}\text { Mano } \\
\text { tautinis } \\
\text { tapatumas }\end{array}$ & $\begin{array}{l}\text { Šalies gynyba prasideda nuo } \\
\text { tautinio ir kultūrinio identiteto } \\
\text { išlaikymo (11). } \\
\text { Mano, kaip kariūno, esama ir } \\
\text { būsima profesinè veikla susiju- } \\
\text { si su tautiniu tapatumu trimis } \\
\text { dalykais: istorijos puoselèji- } \\
\text { mu, lietuvišku papročiu lai- } \\
\text { kymusi, man brangiu žmoniu } \\
\text { saugumu (8). Lietuvos karo } \\
\text { akademijoje yra ugdomos ne } \\
\text { tik inteligento, bet ir patrioto } \\
\text { savybès (15). }\end{array}$ \\
\hline
\end{tabular}

Analizuodami išskirtas subkategorijas, galime daryti prielaidas, kad kariūnai kalba (žodžių, sakinių prasminiais vienetais) išreiškè vertybines nuostatas, perteikè igytas žinias, reflektavo patirtis holistiškai jas siedami. Respondentų tautinès kultūros įgymis reflektuojant savo tapatybę susijęs su jų ịgijiniu (L. Jovaiša, 2007). Turèdami tam tikrą paveldimą struktūrą, perimtą iš tèvų ir ankstesnių kartų, būsimieji kariūnai ịgijimo proceso metu papildo ją iš aplinkos (kultūrinès ir ugdomosios), susikuria patys savarankiškai veikdami.

Lyginant pirmo ir ketvirto kurso respondentų kalbinę raišką fiksuojamas ryškus skirtumas vertinant kalbos stilių. Jei pirmo kurso studentų esė darbuose yra nemažai meninio stiliaus elementų, kurie susilieja su publicistiniais, tai baigiantieji studijas kariūnai kalba dalykine-moksline kalba, kurioje vyrauja specialybės terminai, tarptautiniai žodžiai (priemonè, konstanta, komunikacija, tarpkultūrinė erdvè). Ilgi sakiniai rodo minties daugiasluoksniškumą, turimų žinių kiekị. Asmeniui nutolstant nuo gimtosios vietos žodynas siaurejja, stilistiškai nuspalvinti žodžiai traukiasi iš vartosenos, i jų vietą braunasi neutralioji leksika.

Jei $2011 \mathrm{~m}$. kalbėdami apie tautinị tapatumą karo akademijos studentai daugiau dèmesio skyrè savęs pažinimui, savęs kaip tautos atstovo apibėžčiai, tai 2015 m. ryškus vertinamasis aspektas. Emociniu požiūriu jautresni pirmakursių pasisakymai. Jie kalbiniu požiūriu yra emocingesni, spalvingesni. Bebaigiantieji studijas daugiau koncentruojasi ị pareigos šeimai akcentavimą, tautiškumą apskri- 
tai. Savitumą, išskirtinumą savo kalba jie lyg praradę. Galima daryti prielaidą, kad tai-globalizacijos pasekmè.

Kaip tautos kultūrą pažista būsimieji karybos specialistai? Šalies, kurioje gyveni, kalba - jos kultūros dalis. Tautos kultūrą detaliau pažịsta pirmakursiai: jie tautiškumą sieja su krašto istorija, kalba, literatūra, muzika ir kitais kultūros reiškiniais. Ketvirto kurso studentai, matyt, detaliau gilinosi ị specifinės (karinès) krypties dalykus. Tai matyti ir iš jų kalbos - gausu profesionalizmų. Jie ị Lietuvą žvelgia profesionalo akimis: vertina jos geografinę padètị, infrastruktūrą, daug mažiau dèmesio skirdami kultūrai. Globalaus pasaulio antspaudas ryškus 2015 metu respondentų kalboje.

Gimtają kalbą 2011 metų tyrimo dalyviai puoselèjo, ja didžiavosi, laikè savo tautinio identiteto ryškiu akcentu. Praejjus ketveriems metams respondentų požiūris pasikeite. Gimtoji kalba vieniems tapo tik komunikacijos priemone, o kitiems - ji ir toliau yra pasididžiavimo ir jausmų artimiesiems raiškos forma. Galime daryti prielaidą, kad pirmosios grupès respondentų tautinis tapatumas buvo daugiau paviršinis, deklaratyvus. Antrosios grupès dalyviai turejo tvirtesnị tautinị tapatumą - jo nepajègè išdildinti nei kitokios nuomonès, nei aplinkos veiksniai.

Kultūra, kaip vertybių sistema, ịprasmina dvasinių jègų ir materialiają jos raišką visuomenèje kalba ir veikla. Tai - žmogaus veiklos pagrindas, parodantis, kaip, kokiais principais vadovaujasi žmogus. Vertybių ugdymas(is) formuoja visapusiškai išsilavinusį žmogų. Lietuvos piliečio vertybinis tautinis dėmuo susidūrè su globalaus pasaulio iššūkiais.

Kiekybine tyrimo duomenų analizė buvo atlikta siekiant nustatyti aukštą, vidutinį ar žemą respondentų kultūrinio identiteto raiškos lygmenį. Pasirinkti tokie kiekybinès analizès kriterijai: emocinis vertinimas, pažintinis interesas (stipriosios ir silpnosios pusès), tautiniai ir pilietiniai praktiniai gebėjimai, tautinio identiteto idejjų, jausmų, veiksmų prielaidos (žinos ir metodai, jų praktinis taikymas), vertybinès nuostatos. Duomenys buvo skaičiuojami procentais analizuojant esè tekstą, nustatant reikšminius kalbos vienetus pagal penkis kriterijus (žr. 2 lentelę). 
2 lentelè. Respondentų kultūrinio identiteto raiškos lygmenys

\begin{tabular}{|c|l|c|c|c|c|c|c|}
\hline \multirow{2}{*}{$\begin{array}{c}\text { Eil } \\
\text { nr. }\end{array}$} & \multicolumn{2}{|c|}{ Kriterijai } & \multicolumn{2}{c|}{$\begin{array}{c}\text { Aukštas } \\
\text { lygmuo (\%) }\end{array}$} & \multicolumn{2}{c|}{$\begin{array}{c}\text { Vidutinis } \\
\text { lygmuo (\%) }\end{array}$} & \multicolumn{2}{c|}{$\begin{array}{c}\text { Žemas } \\
\text { lygmuo (\%) }\end{array}$} \\
\cline { 3 - 8 } & & $2011 \mathrm{~m}$. & $2015 \mathrm{~m}$. & $2011 \mathrm{~m}$. & $2015 \mathrm{~m}$. & $2011 \mathrm{~m}$. & $2015 \mathrm{~m}$. \\
\hline 11. & Emocinis vertinimas & 11,8 & 8,9 & 46,2 & 57,6 & 41 & 33,5 \\
\hline 22. & Pažintinis interesas & 24 & 64,2 & 56,3 & 19,7 & 20,7 & 16,1 \\
\hline 33. & $\begin{array}{l}\text { Tautiniai ir pilietiniai } \\
\text { praktiniai gebejjimai }\end{array}$ & 20,5 & 14,5 & 56,3 & 26,8 & 23,2 & 58,7 \\
\hline \multirow{2}{*}{ 44. } & $\begin{array}{l}\text { Tautinio identiteto idèjų, } \\
\text { jausmu, veiksmų prielaidos }\end{array}$ & 30,7 & 20,4 & 48,6 & 37,2 & 20,7 & 42,4 \\
\hline 55. & Vertybinès nuostatos & 25,8 & 21,3 & 64 & 57,8 & 10,2 & 20,9 \\
\hline & Vidurkis & 22,5 & 25,86 & 54,3 & 39,82 & 23,2 & 34,32 \\
\hline
\end{tabular}

Lyginant I ir IV kurso kariūnų kalbos tyrimo rezultatus pagal lygmenis, akcentuotinas emocinio vertinimo mažėjimas, išaugęs pažintinis technologinis, tarpkultūrinis interesas, nykstantys kariūnų tautiniai ir pilietiniai praktiniai gebejjimai, tačiau vertybinès nuostatos išlieka aukšto $(21,3 \%)$ ir vidutinio $(57,8 \%)$ lygmens. Tai teikia vilčių, kad būsimieji karininkai garbingai atstovaus savajai kultūrai ir tautai.

\section{Išvados}

1. Globalizacijos plètros sąlygomis keičiasi požiūris į tautiškumą, pilietiškumą. Didžiausi iššūkiai tautiniam tapatumui, yra šie: nacionaliniai ịstatymai automatiškai derinami su ES ịstatymais, nacionalinè pilietybė tampa ir europine; silpsta gynybinè tautinès valstybès funkcija, nes darosi mažiau veiksmingas toks ,patriotinio auklejjimo" būdas, kaip karo tarnyba; medijos dažnai skiepija kosmopolitinị požiūrị.

2. Kalboje atsispindi tautos intelektualumas, socialinis charakteris, meninis polinkis, estetiniai sugebejjimai, pasaulio suvokimo būdas, mąstysena ir pasaulèvaizdis - visas jos individualumas. Kalba - esminis tautos narių jungiamasis ryšys, pasireiškiantis daugelyje lygmenų: nuo kasdienio, buitinio bendravimo iki filosofijos, poezijos ir aukščiausių žmogaus dvasios atsiskleidimų.

3. Empirinio lyginamojo tyrimo rezultatai atskleidè, kad būsimieji karininkai, vis labiau jaučiantys globalizacijos pasekmes, modernejja: jų tautinis kultūrinis identitetas iš esmès koreliuoja su turimų kultūrinių žinių kokybe ir jų įsisąmoninimo lygiu, susiformavusiu protinès veiklos būdu ir veiklos projektavimo bei aktyvumo interesu. Tai yra dvasinių vertybių ir emocinių išgyvenimų bei aktyvinamosios veiklos pagrindinis šaltinis. Naudodamiesi integralių žinių, gebẻjimų ir įgūdžių kompleksu, ugdymo erdveje kariūnai atsiveria perspektyvioms, autentiškoms asmeninio daugiau globalaus (tarpkultūrinio) negu tautinio identiteto tobulèjimo juslèms. 


\section{Literatūra}

1. Ambrazas, V. (1989). Ar išslaugysime? Mintys apie gimtaja kalbą. Vilnius: Mokslas, p. 4-6.

2. Astra, L. (2006). Tautiškumo ir lietuvių tapatumo problemos globalioje modernybejje. In: Lietuviškojo europietiškumo raida: dabarties ir ateities iššūkiai. Vilnius: Kultūros, filosofijos ir meno institutas.

3. Antinienè, D. ( 2012). Žmonių santykiai organizacijose. Kaunas: Technologija.

4. Bitinas, B.; Rupšienė, L.; Žydžiūnaitè, V. (2008). Kokybinių tyrimų metodologija, I ir II dalis. Klaipėda: S. Jokužio leidykla.

5. Buber, M. (1998). Dialogo principas I. Vilnius: Katalikų pasaulis.

6. Bukantienè, J.; Janulaitienè, N.; Tijūnèlienè, O. (2014). Lithuanian Academic Youth's Expression of National Cultural Identity: a Case Study. In: General and Professional Education, No. 3, pp. 57-64.

7. Castels, M. (2006). Tapatumo galia. Vilnius: UAB „Poligrafija ir informatika“.

8. Christensen, C. R. Center for Teaching and Learning, Harvard Business School, 2010 // Case Method in Practice [žiūrèta 2015-04-21]. http:/www.hbs.edu/ teachingandlearningcenter/in-practice/

9. Duoblienè, L. 2006. Tarpkultūrinis ugdymas: tautinio tapatumo ir(ar) dialogo paieškos. In: Lietuva globalejančiame pasaulyje. Vilnius: LOGOS, p. 224248.

10. Gee, J. (1998). Preamble to a Literacy Program. Madison: Department of Curriculum and Instruction.

11. Giles, H.; Taylor, D.; Lambert, W.; Albert, G. (1976). Dimensions of Ethnic Identity: an Example from Northern.

12. Giddens, A. ( 2000). Modernumas ir asmens tapatybè. Vilnius. Pradai.

13. Husserl, E. (2005). Korteziškosios meditacijos. Vilnius: Aidai.

14. Jančaityte, R.; Valavičienè, N.; Augutienè, R. ir kt. (2009). Tarpkultūrinès kompetencijos didinimas bei ịvairovès valdymo gebejjimų stiprinimas. Projekto „Supratimo link“ tyrimo rezultatai. Vilnius: Mykolo Romerio universitetas.

15. Jovaiša, L. (2007). Enciklopedinis edukologijos žodynas. Vilnius: Gimtasis žodis.

16. Kuzmickas, B. (2006). Lietuviškasis europietiškumas - ką žada skirtingos istorinès patirtys. In: Lietuviškojo europietiškumo raida: dabarties ir ateities iššūkiai. Vilnius: Kultūros, filosofijos ir meno institutas, p. 56.

17. Kuzmickas, B. (2007). Tautos tapatumo savimonè. Lietuvių savimonès bruožai. Vilnius: Mykolo Romerio universitetas.

18. Kuzmickas, B. (2013). Vertybès kultūrų kontekstuose. Vilnius: Mykolo Romerio universitetas

19. Lietuvos pažangos strategija 2030. (2012). [žiūrèta 2012-02-05]. Prieiga 
per internetą: http://www.lietuva2030.lt/images/stories/projektas.pdf.

20. Lyotard, J. F. (2010). Postmodernus būvis. Ataskaita apie žinojimą. Vilnius: Baltos lankos.

21. Luobikienè, I. Sociologinių tyrimų metodologija. Kaunas: Technologija, 2010 .

22. Maceina, A. (1998) . Mintys ir apmąstymai. Vilnius: Eugrimas.

23. Maceina, A. (1990). Pedagoginiai raštai. Kaunas: Šviesa.

24. Martinaitis, M. (1989). Ko moko motina gramatika. In: Mintys apie gimtają kalbą. Vilnius: Mokslas, p. 9-18.

25. Martišauskienè, E.; Juškevičienè, A. (2011). Gimtosios kalbos puoselejjimas kaip penktokų tautinio ugdymo veiksnys. Pedagogika, Nr. 103, p. 7-14.

26. Mejè, A. (Antoune Meillet). Prieiga per internetą: https://en.wikipedia. org/wiki/Antoine_Meillet. [žiūrèta 2016-03-14].

27. Norvilas, A. (2013). Tauta, kalba ir tapatybė. Vilnius: Vilniaus universiteto leidykla.

28. Sheilsas, J. (1995). Kalbų mokymasis ir mokymas bendrauti. Vilnius: Leidybos centras.

29. Sears D. O \& PJ Henry PJ. (1999). Ethnic Identity and Group Threat in American Politics. In: The Political Psychologist, 4, 12-17.

30. Tarptautinių žodžių žodynas. (2008). Vilnius: Alma Littera.

31. Usher, R.; Edwards, R. (2008). Globalization and Pedagogy: Space, Place and Identity. 2nd edition. London and New York: Routledge. Prieiga internetu: http;//ezproxy, \.biblioteka.ku.lt:2063/ehost/ebookviewer/ebook/e000xww_79891 AN?sid=20c40ef0-bffd-4567-a5d2-86e265261feb@sessionmgr13\&=2\& format+EB [žiūrèta]: 201603 10].

32. Vabalaite, R. M. (2006). Modernioji tapatybès samprata. In: Lietuva globalejančiame pasaulyje. Vilnius: LOGOS, p. 129-148.

33. Valstybinè švietimo 2013-2022 metų strategija [žiūrèta 2014-03-03]. Prieiga per internetą: http://www3.1rs.lt/pls/inter3/dokpaieska.showdoc_1?p_ $\mathrm{id}=438859$.

34. Veiksmų plano „Kalbų mokymosi ir kalbų ịvairovès skatinimas“ igyvendinimo ataskaita. Briuselio komunikatas (2007). Prieiga per internetą: http:// ec.europa.eu/educatio/lifelong-poliy/doc/lang/com554_lt.pdf [Žiūrèta 201603 14].

35. Vydūnas (1921). Mūsų kalbos mokymas Lietuvos mokyklose. Darbymetis, Nr. 3.

36. Vydūnas (1990). Raštai, I t. Vilnius: Mintis.

37. Zaborskaitè, V. (1993). Apie kalbą. In: Gairès. Kaunas: Šviesa, p. 57-61.

38. Zabotka, A. (1989). Ar branginame tėvų kalbą. In: Mintys apie gimtaja kalba. Vilnius: Mokslas, p. 18-27. 


\title{
MOTHER TONGUE AS A WAY TO MEASURE FUTURE OFFICERS' EXPRESSION OF NATIONAL CULTURAL IDENTITY
}

\author{
Assoc. Prof. Dr. Janina Bukantienè \\ Klaipeda University \\ Assoc. Prof. Dr. Nijolė Janulaitienè \\ The General Jonas Žemaitis Military Academy of Lithuania \\ Prof. Habil. Dr. Ona Tijūnelienė \\ Klaipéda University
}

\section{Summary}

The relevance of the selected topic is confirmed by the EU Language Policy promoting linguistic diversity as well as Lithuania's most recent documents which establish the principles, such as national identity, continuation of the tradition to discover the past and openness to cultural diversity. Moreover, one of their main objectives say that at the age of globalization it is important to reconsider one's national identity.

The object of the research is the significance of native language for the formation and expression of academic youth's national identity.

The research problem is a native language as a way to measure academic youth's expression of national cultural identity.

The goal is to investigate and identify the significance of native language for the future officers' national cultural identity and the change of its expression.

Globalization is a factor destroying a person's national cultural identity which, as a result, is changing the attitude towards nationalism and citizenship. The biggest threats to national identity today are as follows: national legislation is automatically aligned with the EU legislation, national citizenship is becoming European, national defence function of a state and its role are getting weaker and cosmopolitan attitudes are popularized by the media.

Language is a way to measure the expression of nation's individuality. It reflects the nation's intelligence, social character, artistic inclination, aesthetic skills, world's perception, mindset and world view, i.e. all of its individuality. Through a native language a person is associated with his/her own existence and the people. Therefore, attachment to a mother tongue is automatic and instinctive. Language is a key link connecting the people of a nation which manifests itself in many levels: from everyday and domestic communication to philosophy, poetry and prayer, the highest unfolding of the human spirit.

The results of the empirical comparative study show that due to more profound effects of globalization, future officers are getting more modern as their national cultural identity is essentially correlated with the quality of the existing cultural knowledge and its awareness level which is formed via mental practices and activities. It is the main source of their spiritual values, emotional experiences and activities. Using a complex of integral knowledge, abilities and skills while learning, cadets open up to promising authentic personal development of a rather global identity while using their own language. 


\section{AUTORIŲ LYDRAŠTIS}

Autoriaus vardas, pavardè: Janina Bukantienè

Mokslo laipsnis ir vardas: socialinių mokslų (edukologija) daktarè

Darbo vieta ir pareigos: Klaipèdos universiteto Pedagogikos katedros docentè, S. Nèries g. 5, LT- 92227, Klaipèda

Autoriaus mokslinių interesų sritys: gimtosios kalbos didaktika, kalbinè komunikacija, vertybių pedagogika.

Telefonas ir el. pašto adresas: (8 46) 398624 (darbo), jbukantiene@gmail.com

Autoriaus vardas, pavardè: Nijolè Janulaitienè

Mokslo laipsnis ir vardas: socialinių mokslų (edukologija) daktarè

Darbo vieta ir pareigos: Generolo Jono Žemaičio Lietuvos karo akademijos Humanitarinių mokslų katedros docentė, Šilo g. 5A, LT-10322 Vilnius

Autoriaus mokslinių interesų sritys: ugdymo mokslo istorija, teorija ir praktika, kariūnų atranka ị Generolo Jono Žemaičio Lietuvos karo akademiją

Telefonas ir el. pašto adresas: (85) 2387063 (namų), njanulaitiene@gmail.com

Autoriaus vardas, pavardè: Ona Tijūnèlienè

Mokslo laipsnis ir vardas: habilituota socialinių mokslų (edukologija) daktarè

Darbo vieta ir pareigos: Klaipedos universiteto Pedagogikos katedros profesorè, S. Nèries g. 5, LT- 92227, Klaipėda

Autoriaus mokslinių interesų sritys: ugdymo filosofija, vertybių pedagogika, mokslinio darbo metodologija, lietuvių kalbos problemos

Telefonas ir el. pašto adresas: (8 46) 398624 (darbo), onatij@one.lt

\section{AUTHORS' COVER LETTERS}

Author's name and surname: Janina Bukantienè

Academic degree and name: Doctor of Social Sciences

Workplace and position: Klaipèda University, Department of Pedagogy, Associate Professor

Author's research interests: native language didactics, development of linguistic communication, ethics of pedagogy

Telephone and e-mail address: (8 46) 398624 (office); jbukantiene@gmail.com

Author's name and surname: Nijolė Janulaitienė

Academic degree and name: Doctor of Social Sciences

Workplace and position: The General Jonas Žemaitis Military Academy of Lithuania, Department of Humanities, Associate Professor

Author's research interests: history, theory and practice of education sciences, selection system to the Military Academy of Lithuania

Telephone and e-mail address: (8 5) 2387063 (home); njanulaitiene@gmail.com 
Author's name and surname: Ona Tijūnèlienè

Academic degree and name: Professor, Habilitated Doctor of Social Sciences

Workplace and position: Klaipeda University, Department of Pedagogy, Associate Professor

Author's research interests: methodology of pedagogical research, pedeutology, ethics of pedagogy, philosophy of pedagogy, values philosophy, history of pedagogy, problems of Lithuanian language

Telephone and e-mail address: (8 46) 398624 (office); onatij@one.lt 